\title{
Survey battle leads to plagiarism verdict
}

Hong Kong and Tokyo. A bitter dispute between two epidemiologists at the University of Hong Kong has, after a court battle lasting seven years and costing over HK $\$ 16$ million (US\$2.1 million), resulted in the world's first legal verdict in which a scientist has been found guilty of plagiarism.

In August, an appeals court in the British colony confirmed the verdict of Hong Kong's High Court in April last year that Lam Tai Hing, a reader in the university's department of community medicine, had made unauthorized use of a questionnaire devised by a lecturer in the same department. An internal inquiry is now underway in the university to determine if Lam should be dismissed.

But the verdict has split the world of epidemiology. Some researchers welcome the way it has focused attention on the value of questionnaires as research tools, and the amount of original effort that can go into their compilation. Others claim that the extent of the plagiarism was relatively limited, and that the court ruling sets a dangerous precedent for the future progress of epidemiology. Some even describe it as a "miscarriage of justice".

The conflict began in January 1980, when the then head of the university's community medicine department, Michael Coulbourne, introduced Linda Koo, a new lecturer in the department, to his collaborator John Ho Hung Chiu, honorary professor of radiation oncology at the university.

Coulbourne encouraged the two to continue research which he and Ho had been carrying out into the unusually high incidence of lung cancer in non-smoking Chinese women. At the end of the same year, Coulbourne, having retired from the department, encouraged Lam Tai Hing, another lecturer then on a postgraduate course in Britain, to take up the same line of research.

Over a period of 20 months, Koo and Ho drafted 14 versions of a questionnaire, which in its final form included 69 main questions, and numerous subquestions. They then carried out fieldwork, which was completed in April 1983.

Lam returned to Hong Kong in October 1981. Supported by the new head of the department, J. W. L. Kleevans, he obtained a separate grant, and began work on his own questionnaire, which passed through four stages of drafting.

At this point, claims Koo, amicable relations in the department began to deteriorate. Lam and Kleevans approached Ho to join Lam's project, but Ho declined. Koo alleges she was subsequently harassed and victimized by Kleevans and Lam; Kleevans admitted in court that he had suggested she leave the department on at least three occasions.

In 1986, Koo says she began to suspect that Lam had used parts of her questionnaire

to construct his own. He admitted having a copy of her questionnaire, but denied using it in his own work, and claimed that she had given it to him.

Koo and Ho appealed to the university vice-chancellor. But attempts at mediation failed, and one month later the two researchers issued a writ against Lam, charging infringement of copyright and misuse of confidential information.

The subsequent court case focused on the degree of similarity between the two questionnaires, including both the final and draft versions - making comparison a difficult and time-consuming process - and on whether epidemiological researchers usu-

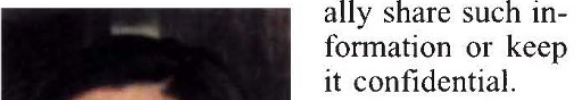

One witness

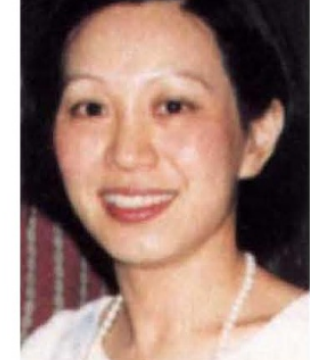

Koo: victor in court case

smoking women.

Maclennan pointed out apparent similarities in some of the questions and their sequence in the two sets of questionnaires, and argued that the likelihood of Lam creating his independently was "extremely low", a view that was backed up by a British linguistics expert. He also argued that few investigators are willing to share their questionnaires at an early stage in their research.

But Richard Peto, director of the Cancer Studies Unit at the University of Oxford in Britain, a world-respected authority on links between smoking and cancer, argued in Lam's defence that there was very little similarity between the questionnaires.

Peto claimed that it was normal practice for epidemiology researchers to share information about their questionnaires, and argues that these should not be subject to copyright protection.

Whatever the merits of such arguments, Lam's case was weakened by the fact that, after six years of denial, he eventually admitted that he may have made some limited use of Koo and Ho's questionnaire in formulating his own. The court subsequently ruled that he had infringed Koo and Ho's copyright, and misused confidential information that he had obtained "surreptitiously".

The appeal court upheld this verdict, but stated that the word "surreptitiously" did not mean that Lam "stole" the question- naire. Rather, the court ruled that he had come into possession of a document which he knew was confidential and was not entitled to use.

Peto feels strongly that the courts' findings are a miscarriage of justice. "If people were to put the two [final] questionnaires side-by-side, they would see that there has been no impropriety," he says. But the transcript of the hearing shows that the court was persuaded by "substantial" similarities between earlier versions of the two questionnaires.

Suketami Tominaga, director of the Aichi Cancer Center Research Institute, who says that Japanese epidemiologists usually share questionnaires, even in the early stages of research, suggests that competing epidemiologists "should get permission" to use elements from a questionnaire compiled by another researcher.

Takeshi Hirayama, formerly of the National Cancer Institute in Tokyo, whose studies in the 1960s were among the first to link passive smoking to lung cancer, says that the important factor to emerge from the case is the originality of questionnaires. "Success or failure of a study depends on the quality of the questionnaire," he says.

Hirayama says he supports Peto and Maclennan, and that he is saddened by the court case. He describes Lam as a "good researcher", and Koo as a driving force in the argument that diet is an important cofactor in lung cancer in non-smoking women.

H. K. Ma, the dean of the medical faculty of the University of Hong Kong, says the university's internal inquiry will try to determine the "degree and seriousness" of Lam's plagiarism, describing him as "one of the faculties most respected academics".

Koo's charges of harassment and victimization have yet to be thoroughly investigated. These have been made on numerous occasions, including in a letter to the university's vice-chancellor in January 1987, when Ho and Koo complained about the actions of Kleevans, including restricting Koo's access to department facilities, blocking her application for a grant, and trying to persuade her to give up research on lung cancer.

But the university did not investigate the charge at the time because, it claims, the whole issue had been made sub judice by the court case, adding that, as Kleevans left the university in 1987, "there would seem to be little point in pursuing that issue now".

Koo feels she is being victimized as a whistleblower, and points out that while Lam has been promoted during the trial to reader, she has remained a lecturer for 13 years. Ma says she is unaware of the 1987 complaints, but has investigated more recent charges made by Koo against the present head, and has found "no grounds at all" for complaint.

David Swinbanks 